\title{
A history of South African (SA) Psychology
}

\section{Historia de la psicología sudafricana}

Envio 12/12/2013 | Revisión 26/07/2014 | Aceptación 03/08/2014

\section{NichOlas, LiONEL J. *}

Psychology Graduate Assistant School of Health Sciences

Monash South Africa. South Africa

doi:10.11144/Javeriana.upsy13-5.hsap

Para citar este artículo: Lionel, N. (2014). A history of South African (SA) psychology. Universitas Psychologica, 13(5), 1983-1991. http://dx.doi. org/10.11144/Javeriana.upsy13-5.hsap

lionel.nicholas@monash.edu

\section{A B S T R A C T}

This historical account of SA psychology spans over hundred years of its engagement with international psychology and the influence of racism on its development. It traces Jan C. Smuts's correspondence with Adler, Koffka and Perls and Allport's extensive contact with SA psychologists. The positive impact of the academic boycott in turning psychology towards the concerns of the oppressed is delineated, as well as the response of professional organizations to apartheid. The extensive reciprocal visits of US and Dutch phenomenologists are described and the contributions of Wolpe, Rachman and Lazarus to behavior therapy are noted.

Keywords

History of Psychology; South Africa

\section{RES U MEN}

Este recuento histórico de la psicología en SA se extiende por más de cien años, desde su alianza con la psicología internacional y la influencia del racismo en su desarrollo. Se traza la correspondencia de Jan C. Smuts con Adler, Koffka y Perls y el amplio contacto de Allport con psicólogos SA. El impacto positivo del sabotaje académico en la transformación de la psicología hacia las preocupaciones de los oprimidos está delineado, así como la respuesta de las organizaciones profesionales al apartheid. Se describen las extensas visitas recíprocas de los fenomenólogos de Estados Unidos y los Países Bajos y se señalan las contribuciones de Wolpe, Rachman y Lázaro a la terapia de comportamiento.

\section{Palabras claves}

historia de la psicología; Sudáfrica 


\section{Introduction}

The most defining characteristic of the history of South African (SA) psychology is related to the extent to which SA psychologists engaged with major international psychologists during the early development of psychology. Its second defining characteristic is related to the extent to which politics and race were intertwined with SA psychology (Cooper \& Nicholas, 2012; Nicholas, 2013).

\section{Jan Christiaan Smuts}

Jan Christiaan Smuts (1870-1950) Prime Minister of SA $(1919-1924 ; 1939-1948)$ was the first South African to be regarded as an important psychologist internationally (Annin, Borig, \& Watson, 1968). Smuts was a lawyer, but during his undergraduate studies at Oxford University he produced a manuscript in 1895, analyzing the personality of Walt Whitman, the famous American poet (Blanckenberg, 1951). The manuscript was considered commercially unviable and was only published in 1973 (Smuts, 1973). Smuts's next manuscript was completed in 1910, 'An inquiry into the whole', revised in 1924 and published in 1926 as Holism and evolution (Smuts, 1926). Smuts coined the term 'holism' and his book caught the eye of Alfred Adler who requested Smuts's permission to have the book translated into German and published in Germany. In his letter (31 January 1931) Adler stated that he recommended Holism and evolution to all his students and followers as the best preparation for the Science of Individual Psychology (University of Cape Town (UCT) Libraries, Special Collections).

Smuts gave permission for the translation and publication of Holism and evolution and it was eventually published in 1938 and translated by H. Minkowski (Blanckenberg, 1951). The books were destroyed during World War II after the Nazi government removed it from circulation (van der Poel, 1973). Smuts and Adler continued their correspondence and he invited Smuts to be one of the three judges of the best book on the history of wholeness with reference to Individual Psychology in a letter of June 141931 (UCT Libraries, Special
Collections). They eventually met in Berlin and had an extended conversation (Blanckenberg, 1951). Smuts refused repeated requests for a new edition of Holism and evolution believing that the scientific basis of the book had weaknesses. Smuts believed that he could make a particular contribution to the theory of personality but felt that psychology was too analytical and therefore proposed that a new discipline 'personology' should be established with the aim of examining personality and its phases, as well as development in a holistic manner. Personology would therefore study personality:

(...) in its unique wholeness and unity, rather than, in the way of psychology, as a series of separate abstracted activities. Personology would study the Personality not as an abstraction or bundle of psychological abstractions, but rather as vital organism, as the organic psychic whole which par excellence it is; and such a study should lead to the formulation of the laws of the growth of this unique whole, which would not only be of profound theoretical importance, but also of the greatest practical value. One cannot read the lives of the great personalities without feeling that a vast field for first-class scientific and philosophic research remains still unexplored, and that discoveries of the highest importance await the student of Personology. (Smuts, 1926, pp. 290-291)

Smuts (1926) regarded psychology as too impersonal to study great personalities and believed that the artistic, ethical and spiritual values, which they embody, related to the holistic tendency of the personality, best studied via personology. Smuts did however not explore the idea of personology further because he was more concerned with laying the foundation for the holistic concept, but he did not return to either topic (Blanckenberg, 1951). Smuts also tried to include the term 'personality' in the preamble of the United Nations Organization (UNO) Charter. Smuts contributed to the Charter, writing the original preamble, which was subsequently changed. This was however changed to 'person' in the final version of the preamble of the Charter (Dubow, 2008). Ironically a special commission of the UNO found that the policies 
of apartheid, of which Smuts was a staunch supporter, contravened the Charter and its Preamble (Dubow, 2008).

Smuts corresponded with Kurt Koffka who sent Smuts books by himself and Mary Harrower, a former colleague and student (who was born in South Africa) on experimental psychology because they illustrated the influence of holism:

These books may interest you in that they show how holistic principles are required in psychology and how they influence the active experimental work of the psychologist who with their help may even some day hope to approach the problem of personality. (William Cullen Library Archive, University of Witwatersrand, Wits)

Harrower developed a Rorschach test for groups called the Harrower blot (Saxon, 1999).

\section{Psychology in SA before World War II}

It was common for English-speaking SA psychologists to obtain PhD's in the United Kingdom and for those speaking Afrikaans to travel to Holland and Germany to obtain PhD's (Strümpfer, 1993). Some SA psychologists also completed PhD's in the USA. E.G. Malherbe for example, completed his studies at Columbia, working with John Dewey and E. L. Thorndike. He also had some contact with Terman at Stanford and knew Sir Cyril Burt, the doyen of British psychologists, before Burt faked, his twin studied data, intimately from the 1920's (Kamin, 1974; Malherbe, 1981a, 1981b). Malherbe returned to South Africa and pioneered psychometric testing in the 1930's. He was Smuts's Director of Military Intelligence and Chief of Army Educational Services and thereafter was the founding Rector of the University of Natal from 1945-1965 (Malherbe, 1981a).

R. W. Wilcocks established the first independent SA psychology department in 1917 at the University of Stellenbosch. Others psychology departments, still housed in philosophy departments, followed suit (Louw \& Foster, 1991). Wilcocks had completed his $\mathrm{PhD}$ at the University of Berlin in
1917 and established the first experimental psychology laboratory modelled along the lines of Wundt's laboratory. Wilcocks joined Malherbe in large scale psychometric testing of poor Whites in the 1930s.

\section{The beginnings of psychoanalysis in SA}

The psychoanalytic perspective was a major historical orientation in the early development of SA psychology. MacCrone (1937, p. 309) provided the following psychoanalytic explanation for racial conflict in SA:

Bearing in mind what has already been said about the role of the black man in the white man's own Unconscious, we may conclude that some of the hostility felt by the white man is of that sadistic kind in which a fusion of the aggressive and erotic impulses comes to be displaced upon the man with black skin. In that case the hostility represents an indirect gratification of impulses, which leads directly to the development of a sense of guilt or fear of punishment by the white man's own Super-Ego and hence to an increase in anxiety. But this increase in anxiety will only exacerbate hostility, so that we have a vicious circle in which hostility and anxiety, as alternately cause and effect, reinforce one another. The more or less neurotic white man and woman, whose own internal conflicts are only partially overcome, tend to externalize and project them in the form of a conflict between white and black, so that the mental conflict of the individual becomes the paradigm for a racial conflict.

He also believed that the legislation, which criminalized sexual intercourse between black and white (The Immorality Act), could be explained through 'displacement' as its real purpose was to prevent the 'mixed' offspring that would result (MacCrone, 1937). MacCrone (1937) investigated the puritanical Calvinist personality type and his factor analytic studies identified a personality structure characterized by an ethnocentric outlook and negative attitudes toward Blacks (followers of John Calvin believed that humanity is essentially sinful and that God predestined people to believe in Him). 
MacCrone served as Rector of the University of the Witwatersrand for a number of years after heading the psychology department.

Wulf Sachs, who was a student of Pavlov, arrived in SA in 1922 and returned to Europe in 1930 for training in psychoanalysis. He returned to SA to establish the Psychoanalytic Training Institute. Freud provided an introductory note and suggestions for a manuscript that Sachs (1934) published as Psychoanalysis: Its meaning and application. Sachs (1937) also published a psychoanalytic study of a Rhodesian healer. From 1933 Sachs petitioned the British Psychoanalytic Society (BPS) to recognize a branch in SA but the absence of training analysts in SA made this impossible. The BPS was unsuccessful in their attempt to have analysts relocated to SA, succeeding only with Van Ophuijsen who stayed in SA briefly. Ernst Jones (Freud's biographer) also arranged for Fritz Perls and his family, who were refugees from the Nazis, to travel to SA where they arrived in 1934 and stayed until 1946. Jones however regarded Perls as being '(...) of very imperfect quality as an analyst' (Hayes, 2008, p. 291).

\section{The impact of World War II on SA psychology}

The Perlses and Greek royal family fled the Nazis and spent the war years in Johannesburg and Cape Town, SA respectively (Bertin, 1982). Princess Marie, the last of the Bonapartes, arrived in Durban, South Africa, on July 81941 and settled in Cape Town. In the 1920's, Freud analyzed and trained Bonaparte in analysis at the request of Rene Laforgue after a dinner, which included Otto Rank (Bertin, 1982). Bonaparte assisted Freud financially and paid for his emigration to England in 1938. When Freud repaid her, she used the money to reproduce his collected works, which the Nazis had destroyed. (Bertin, 1982). In Cape Town she lectured on Freud, maintained an analytic practice and arranged meetings of analysts. Sachs, Perls and Bonaparte disagreed about analytic practice. Bonaparte for example believed that Perls was putting Wilhelm Reich's ideas into practice (Bertin, 1982).
Ernst Jones wrote to Max Eilington about the matter:

At the moment he [Perls] is in defiance of Sachs, avowedly training a number of unsuitable candidates and at the same time his regression in the Reichian direction is very pronounced. Sachs asked our Society for help (...). (Hayes, 2008, p. 191)

Perls showed his book, Ego, hunger and aggression to Bonaparte and her negative reaction evoked the following response:

(...) if you don't believe in the libido theory any more, you had better hand in your resignation. Libido theory a matter of faith? I can hardly trust my ears. (http://www.gestalt.org/fritz.htm)

Smuts assisted Bonaparte and the rest of the Greek Royal family to enter South Africa and she stayed in Smuts's house when hers burnt down. Bonaparte and Anna Freud corresponded regularly during her stay in Cape Town as Anna Freud had taken over Freud's role as her confidante and guide. Bonaparte produced two manuscripts while in SA; Myths of war and A lion hunter's dream (Bertin, 1982).

Laura Perls recounted that Fritz and her positions as training analysts were revoked and attributed this to a paper Fritz presented at Marienberg, Czechoslovakia, which incorporated Reich's ideas (Gaines, 1978). Perls was an admirer of Smuts and Clarkson, stated that even though Perls met Smuts only once, he was deeply influenced by Smuts's Holism and evolution and that a large number of his later ideas could be traced to it (Perls, 1947). Perls sent Smuts his book Ego, hunger and aggression on July 141944 stating that:

Although I am completely at a loss how to deal with the problem of collective aggression, the way I have approached this vital question may prove of interest to you. (William Cullen Library, Wits).

Perls and Joseph Wolpe, originator of systematic desensitization, were treating war neuroses in SA at 
the same time and both were becoming disaffected by classic psychoanalysis's ineffectiveness. Perls's major contributions to psychotherapy took shape in SA, which developed into Gestalt therapy and Wolpe became a major figure in behavior therapy (establishing SA as one of three countries (SA, USA and England) to have originated behavior therapy (Gaines, 1979; Kazdin, 1978). Wolpe was mentored by L. J. Reyner who taught at Wits after completing his $\mathrm{PhD}$ with Kenneth Spence, Hull's collaborator at the University of Iowa (Poppen, 1995). Wolpe received the APA Distinguished Scientific Award, which cited him:

For his outstanding contribution to the understanding and modification of abnormal behavior, and in particular for his pioneering work that led to the establishment of behavior therapy. He played a vital role in developing the theory and practice of behavior therapy, currently one of the most widely employed of the therapeutic procedures. Wolpe's therapeutic methods, especially desensitization, have been successfully used to reduce fear and distress in thousands of patients. (APA, 1980, p. 44)

Wolpe supervised and trained Stanley Rachman and Arnold Lazarus who were distinguished internationally. Lazarus's $\mathrm{PhD}$, which Wolpe supervised, was the first study to do a prospective comparison of systematic desensitization and dynamic therapy, the first to use direct observation of behavior as an outcome measure, the first to attempt group desensitization, and may have been the first study to use objective scales to assess phobic avoidance (Dryden, 1991; Poppen, 1995). Lazarus (1958) introduced the term 'behavior therapy' and 'behavior therapist' into the scientific and professional literature and his Behavior therapy and beyond was one of the first cognitive behavioral books and one of the most widely cited of its kind (Dryden, 1991). Wolpe and Rachman (1960) were among the first to challenge psychoanalytic theory applied to the case study of Little Hans.

Wolpe taught his therapy techniques in London while visiting Eysenck on his way to the Centre for Advanced Studies in Behavioral Studies (CASBS), in the USA. While at the CASBS he engaged with Karl Popper, Ernest Hilgard, Edward C Tolman and Mary Cover Jones (Poppon, 1995). Lazarus was invited by Albert Bandura to teach at Stanford with him after Lazarus's $\mathrm{PhD}$ was published in 1961 (Dryden, 1991). Both Lazarus and Wolpe became US citizens and their theoretical disputes became increasingly acrimonious. Lazarus went on to develop his own therapy, Multimodal Therapy (Dryden, 1991; Poppen, 1995).

During World War II Smuts played a pivotal role as a member of the British War Cabinet and in 1945 at the UNO conference he was still widely respected. He is the only signatory to both World War I and II Peace Treaties (Dubow, 2008). In 1946, at the UN he was, however, confronted with his hypocrisy of calling for human rights everywhere except in SA where racism was the official policy. The UN eventually applied sanctions against SA, which would also curtail SA psychologists' international engagements (Cooper \& Nicholas, 2012; Dubow, 2008).

\section{Gordon Allport in SA}

Allport's exposure to SA began with his admiration of SA philosopher R Hoernlé, who taught Allport social ethics while at Harvard University from 1913 to 1920 (Allport, 1960). Hoernlé headed the Wits philosophy department from 1923 to 1943. Allport knew other visiting SA academics to Harvard and exposed his students to the work of South Africans such as E.G. Malherbe, I.D. MacCrone and popular writer Alan Paton. Allport had been corresponding with Malherbe since 1954 and he took Malherbe's advice to visit other SA Universities while in SA (Cherry \& McMillan, 2007). Allport lectured at the Universities of Stellenbosch, Cape Town, Rhodes, Natal and Fort Hare College. His lecture at Fort Hare College (the only Black college he visited) met with negative reactions from the audience because he did not consider the structural aspects of racism or the perspective of oppressed Blacks (Cherry \& McMillan, 2007). In a letter he commented that he did not convince students that frustration need not lead to aggression (Cherry \& McMillan, 2007). 
Ironically Allport, the icon of anti-prejudice, associated with overt racists, The SA Bureau of Racial Affairs while 'suspending' judgement and gave a presentation at the annual conference of the South African Psychological Association, an exclusively White association, which refused membership to Black psychologists (Cherry \& McMillan, 2007, p. 61). Such cozy relationships between White SA psychologists and international psychologists would lead to vociferous opposition to visiting psychologists from a number of Black psychologists. The author as part of the Psychology and Apartheid Committee, for example, stopped the President of the American Psychological Association, J. D. Matarazzo, from speaking at The Psychological Association of South Africa (PASA) annual conference in September, 1989.

While in Durban, Allport conducted research, co-supervised Doctoral and master's theses and gave presentations on prejudice, perception, national character and intergroup conflict. Allport, for example, supervised Jack Mann's $\mathrm{PhD}$ thesis 'The problem of the marginal personality.' Mann was head of the psychology department at Wits during the 1970's. During the 1980's in SA it was thought that marginalized groups would develop a marginal personality characterized by insecurity, self-pity and exaggerated sensitivity. Mann (1957) found no such evidence for the marginality hypothesis (Louw \& Foster, 1992).

Thomas Pettigrew (who had just completed his $\mathrm{PhD}$ with Allport) accompanied Allport to SA and his SA research found that personality factors are similarly important as correlates of prejudice among SA and non-SA samples but do not fully account for the increased intolerance of the SA sample. Pettigrew (1958) found that socio-cultural factors were unusual in accounting for heightened racial hostility. Pettigrew and Allport's visits encouraged SA research on authoritarianism and race attitudes and for Pettigrew '... proved a mind-shaping experience' (Pettigrew, 1993, p. 163). Allport (1960) reported that his visit to SA made him more aware of the socio-cultural factors in prejudice.

Carl Rogers and Ruth Sanford visited SA twice in the 1980's but despite the academic boycott they were welcomed because their objectives were to engage Black and White South Africans as equals and to contribute to lessening racial conflict (Rogers, 1986; Sanford, 1984). Viktor Frankl also visited SA in the 1980's and received an Honorary Doctorate from the University of South Africa in 1984.

Kurt Danziger met Allport during his visit to SA and used Allport's protocols of future biographies of SA students which Allport provided, Danziger developed a theoretical model that linked the structure of future biographies to the limited life chances of their authors (Danziger, 2009). Danziger also met Piaget while he was a doctoral student at Oxford and immersed himself in the Piagetian literature. However, he returned to his older interest in direct research of social behavior and became a world expert on the history of psychology. Danziger left SA on an "exit" permit, which prohibited any return to SA (Brock, 2006; Danziger, 2009).

\section{Professional SA Psychology Associations}

The first professional psychology association, the South African Psychological Association (SAPA) was established in 1948 with 34 members. In 1957, a Black psychologist, Josephine Naidoo, applied for membership and was refused. Simon Biesheuvel, regarded as the doyen of SA psychologists (International Journal of Psychology, 1991) led the discussions regarding Black psychologists's membership of SAPA from 1957 to 1962, without the participation of Black psychologists. When Blacks were eventually admitted to SAPA in 1962 a number of psychologists resigned to establish the Psychological Institute of the Republic of South Africa (PIRSA) on 23 June 1962 restricting the membership to Whites. (See Nicholas, 1990 for a discussion of this issue). Ms Naidoo had during this time withdrawn her application for membership of SAPA, feeling deeply humiliated by the whole experience and soon after left for Canada where she became a professor of psychology (Personal communication, Cape Town, January 1994). Naidoo was Secretary-General of IACCP in the mid-1990s. 
Louw (1987) interpreted SAPA's eventual admission of Blacks as SAPA having taken a stand against apartheid. Nicholas (1990) however argued that;

The concerns of the SAPA members who argued for the admission of blacks centred around avoiding censure from the international community, maintaining standards for all psychologists, and promoting unity and the study of psychology by blacks rather than defeating unjust apartheid laws. (Nicholas, 1990, p. 59)

A further interpretation by Dumont and Louw (2001) contended that the different stances of the two groupings toward race segregation gave them different perspectives on the legitimation of psychology and how they should respond to two powerful audiences, racist SA and the international psychology community.

However, Dumont and Louw (2001, p. 393) quoted Biesheuvel as admitting that he believed it '... virtually impossible for a non-white to become a member'. Biesheuvel also informed Prof. Otto Klineberg, the secretary-general of the International Union of Psychological Science (IUPsyS), that while all races would be admitted to SAPA, regional committees would be allowed to make ad hoc arrangements dictated by their peculiar circumstance. An example of such an arrangement was that the usual official dinner was not arranged for the $14^{\text {th }}$ SAPA annual meeting to avoid Black and White delegates meeting as equals in a social setting (Cooper \& Nicholas, 2012). Therefore, SAPA eventually allowed black membership mainly to retain the advantages of international engagement while hoping for as little contact with black psychologists as possible. The IUPsyS, for example. successfully intervened on behalf of SA psychologists when the Japanese government was about to deny visas to SA delegates to an international conference in Kyoto in 1990. In the 1980's and 1990's the bulk of the contact between SAPA and IUPsyS dealt with admission to international congresses (Dumont \& Louw, 2001). SAPA and PIRSA finally merged in 1983 to establish the Psychology Association of
South Africa, open to all psychologists, but which was still white, and significantly Afrikaner-led!

Van Vuuren (2008) described how leading Dutch phenomenologists engaged with SA psychologists from the 1950's until 1972 when the academic boycott blocked such visits. Dreyer Kruger (the leading figure in SA phenomenological psychology, and a leading light in PIRSA) then initiated visits with a number of US universities. Van Vuuren's (2008) encounter with the academic boycott occurred at a conference in Italy in 1986, where he was required to write a letter of protest against apartheid before being allowed to participate. When he returned to the University of Pretoria (UP), a site of the international phenomenology meetings, he received a severe reprimand for criticizing the government from the Rector of UP. Kruger was also refused to participate in an international conference and vowed never to attend such conferences again (Van Vuuren, 2008). Kruger conveniently forgot that he was a leading segregationist who was part of the committee to devise ways to return SAPA to its formerly exclusively White status (Nicholas, 1990). Kruger's (1979) textbook on phenomenology was prescribed in the US and SA (Van Vuuren, 2008).

The academic boycott contributed a great deal to making professional SA psychology more responsive to mental health problems of Black South Africans, albeit reluctantly. It also forced White psychologists to engage with Black psychologists as equals. PASA, was still unresponsive to the needs of the Black majority and its inability to convince more progressive psychologists to join PASA led to negotiations to form a new body, which would have Black psychologists in its leadership. All organized psychology groupings eventually merged to form the Psychological Society of South Africa (PsySSA) at a conference held at a historically Black university, the University of the Western Cape in 1994, which the author convened.

\section{Conclusion}

SA psychology in the $21^{\text {st }}$ century has been able to build on its 100-year history to become one of the 
most popular subjects, with $12 \%$ of undergraduate enrolment and $10 \%$ of doctoral enrolment in the humanities and social sciences (Academy of Sciences of South Africa, 2011). It recently hosted the first IUPsyS International Congress of Psychology, the first of which was held in Paris in August 1889 in Africa and the first African, a Black South African, was elected IUPsyS President in 2012. While the early history of psychology was marked by the exclusion of Blacks, they are now firmly in the leadership of SA psychology.

\section{References}

Academy of Science of South Africa. (2011). Consensus study on the state of the humanities in South Africa: Status, prospects and strategies. Pretoria, South Africa: Academy of Science of South Africa. Retrieved from www.assaf.org.za/wp-content/uploads/2011Humanity-final-proof-11-August-2011.pdf

Allport, G. W. (1960). Personality and social encounter: Selected essays. Boston: Beacon Press.

American Psychological Association. (1980). Distinguished scientific award for the applications of psychology: 1979. American Psychologist, 35(1), 44-51.

Annin, E. L., Borig, E. G., \& Watson, R. I. (1968). Important psychologists, 1600-1967. American Psychologist, 35(1), 44-51.

Bertin, C. (1982). Marie Bonaparte. London: Quartet. Blanckenberg, P. B. (1951). The thoughts of General Smuts. Cape Town, South Africa: Juta.

Brock, A. C. (2006). Rediscovering the history of psychology: Interview with Kurt Danziger. History of Psychology, 9(1), 1-16.

Cherry, F., \& McMillan, C. (2003). South Africa through the lens of Gordon Allport. In V. Van Deventer, M. Terre Blanche, E. Fourie \& P. Segalo (Eds.), Citizen city: Between constructing agent and constructed agency (pp. 59-69). Cape Town: Captus University Publications.

Cooper, S., \& Nicholas, L. J. (2012). An overview of South African psychology. International Journal of Psychology, 47(2), 89-101.

Danziger, K. (2009). Confessions of a marginal psychologist. In L. P. Mos (Ed.), History of psychology in autobiography (pp. 89-129). New York: Springer Science and Business Media.

Dryden, W. (1991). A dialogue with Arnold Lazarus, 'It depends.' Philadelphia: Open University Press.

Dubow, S. (2008). Smuts, the United Nations and the rhetoric of rights and race. Journal of Contemporary History, 43(1), 45-74.

Gaines, J. (1979). Fritz Perls: Here and now. Millbrae, CA: Celestial Arts.

Gestalt Theory (n.d.). A life chronology: Frederick Perls. Retrieved from http://www.gestalt.org/fritz.htm

Hayes, G. (2008). A history of psychoanalysis in South Africa. In C. van Ommen \& D. Painter (Eds.), Interiors; A history of psychology in South Africa (pp.182-189). Pretoria: Unisa Press.

International Journal of Psychology. (1991). Obituary: Professor Simon Biesheuvel. November, 26(5), 683.

Kamin, L. J. (1974). The science and politics of I.Q. Maryland: Erlbaum.

Kazdin, A. E. (1978). History of behavior modification: Experimental foundations of contemporary research. Baltimore: University Park Press.

Kruger, D. (1979). An introduction to phenomenological psychology. Cape Town: Juta \& Co., Limited.

Lazarus, A. A. (1958). New methods in psychotherapy: A case study. South African Medical Journal, 32, 660-664.

Louw, J. (1987). From separation to division: The origins of two psychological associations in South Africa. Journal of the History of the Behavioral Sciences, 26(99), 58-63.

Louw, J., \& Foster, D. (1991). Historical perspective: Psychology and group relations in South Africa. In D. Foster \& J. Louw-Potgieter (Eds.), Social psychology in South Africa (pp. 57-92). Isando, South Africa: Lexicon.

Louw, J., \& Foster, D. (1992). Intergroup relations and South African psychology: Historical ties. Canadian Psychology, 33(3), 651-656.

MacCrone, I. D. (1937). Race attitudes in South Africa: Historical, experimental and psychological studies. London: Oxford University Press.

Malherbe, E. G. (1981a). Never a dull moment. Aylesbury, UK: Howard Timmins. 
Malherbe, E. G. (1981b). Sir Cyril Burt: The psychologist and the man as I knew him. South African Journal of Education, 1, 73-76.

Mann, J. W. (1957). The problem of the marginal personality. (Unpublished doctoral dissertation). University of Natal, Durban.

Nicholas, L. J. (1990). The response of South African professional psychology associations to apartheid. Journal of the History of the Behavioral Sciences, 26(1), 58-63.

Nicholas, L. J. (2013). Early South African engagement with international psychology. South African Journal of Psychology, 43(3), 289-299.

Perls, F. S. (1947). Ego, hunger, and aggression. London: Allen and Unwin.

Poppen, R. (1995). Joseph Wolpe. London, UK: Sage.

Pettigrew, T. F. (1958). Personality and sociocultural factors in intergroup attitudes: A cross-national comparison. Journal of Conflict Resolution, 2, 29-42.

Pettigrew, T. F. (1993). How events shape theoretical frames: A personal statement. In Stanfield II, J. H. (Ed.), A history of race relations research: First generation recollections (pp. 159-178). London: Sage.

Rogers, C. R. (1986). The dilemmas of a South African white. Person-Centered Review, 1, 15-35.

Rogers, C. R. (1987). The underlying theory: Drawn from experience with individuals and groups. Counseling and Values, 32(1), 38-46.

Sachs, W. (1934). Psychoanalysis: Its meaning and practical applications. London: Cassell \& Co.

Sanford, R. (1984). The beginning of a dialogue in South Africa. The Counseling Psychologist, 12(3), 3-14.
Saxon, G. (1999). Molly Harrower, 93, expert on Rorschach test. [Obituary]. (1999, February 28). New York Times.

Smuts, J. C. (1926). Holism and evolution. New York: McMillan.

Smuts, J. C. (1973). Walt Whitman: A study in the evolution of personality. Detroit: Wayne State University Press.

Strümpfer, D. J. W. (September, 1993). A personal history of psychology in South Africa. Keynote opening address, Congress of the Psychological Association of South Africa, Durban.

University of Cape Town. Special Collections, Harry Oppenheimer Institute, Cape Town, South Africa.

van der Poel, J. (Ed.). (1973). Selections from the Smuts papers (Vol. V). Cambridge, UK: Cambridge University Press.

Van Vuuren, R. (2008). Existential-phenomenological psychology. In C. van Ommen \& D. Painter (Eds.), Interiors: A history of psychology (pp. 204-224). Pretoria: University of South Africa Press.

Wilcocks, R. W. (1932). The poor white problem in South Africa. The report of the Carnegie Commission: Psychological Report. Stellenbosch: Pro Ecclesia Press.

William Cullen Library Archive. University of Witwatersrand, Johannesburg, South Africa.

Wolpe, J., \& Rachman, S. (1960). Psychoanalytic 'evidence': A critique based on Freud's case of Little Hans. Journal of Nervous and Mental Disease, 131, 135-148. 
